\title{
Reseptbasert legemiddelregister: Et viktig verktøy for å oppnå detaljert legemiddelstatistikk
}

\author{
Hanne Strøm \\ Avd. for legemidler, Divisjon for epidemiologi, Nasjonalt folkehelseinstitutt, postboks 4404 Nydalen, 0403 Oslo \\ e-post: hanne.strom@fhi.no Telefon: 23408161
}

\begin{abstract}
Denne artikkelen er tidligere publisert i Norsk Farmaceutisk Tidsskrift 1/2004. Det nasjonale reseptbaserte legemiddelregisteret ble etablert 1. januar 2004 ved Nasjonalt folkehelseinstitutt. Siden opprettelsen, har innsamling av data fra samtlige av landets apotek foregått månedlig. Systemtesting av den tekniske løsningen og validering av data pågår fortsatt. Parallelt arbeides det med å vurdere behovet for og utvikle ulike uttrekk. Prosjektleder Hanne Strøm ved Folkehelseinstituttet mener at opprettelsen av Reseptregisteret må ses på som en svært viktig milepæl - sett fra et farmakoepidemiologisk ståsted. Hun ønsker her å gi Norsk Epidemiologis lesere en helhetlig presentasjon av prosessen som ligger til grunn.
\end{abstract}

\section{BAKGRUNN}

Dagens norske legemiddelstatistikk er basert på salg fra grossister og gir således et begrenset utgangspunkt for farmakoepidemiologisk forskning. På slutten av 1990-tallet ble det fra flere hold pekt på mangelen på data om legemiddelbruk, og for å bedre datatilgangen, ble det foreslått å bygge opp en individbasert reseptstatistikk.

Ved utgangen av 2002 fikk Nasjonalt folkehelseinstitutt (Folkehelseinstituttet) i oppgave fra Helsedepartementet å utvikle og etablere et landsdekkende pseudonymt reseptbasert legemiddelregister. For 2003 bevilget Stortinget 10 millioner kroner til opprettelse av registeret, og Folkehelseinstituttet ble utpekt som databehandlingsansvarlig. Arbeidet har vært organisert som et prosjekt, forankret i divisjon for epidemiologi, avdeling for legemidler.

Folkehelseinstituttets prosjektgruppe har knyttet til seg en ekstern teknisk prosjektleder som har hatt ansvaret for den totale IT løsningen bestående av delprosjektene utvikling av databaseløsning og pseudonymiseringsprosess, samt intern IT struktur. Prosjektet har basert seg på retningslinjer for offentlig anskaffelse.

Prosjektet har i 2003 konsentrert seg om utvikling av de primære funksjonene som muliggjør igangsetting av datainnsamlingen fra apotek fra og med januar 2004. Arbeidet har omfattet

- utvikling og etablering av databasen

- utvikling av pseudonymiseringsprosessen

- tilrettelegging for utarbeidelse av standardrapporter (Kobling med andre helseregistre og avanserte analyser vil bli utviklet senere, men databasen skal være tilpasset dette.)

Reseptregisteret er forankret i Helseregisterloven og hjemlet i egen forskrift [Forskrift om innsamling og behandling av helseopplysninger i Reseptbasert legemiddelregister (Reseptregisteret); vedtatt 17. oktober 2003; www.lovdata.no].

\section{FORMÅL}

Formålet med registeret, slik det er formulert i forskriften (§ 1-3), styrer hva det kan brukes til. Innsamling og behandling av data om legemiddelbruk er viktig for å:

- Kartlegge forbruket i landet og belyse endringer

- Fremme og gi grunnlag for forskning og utredning for å kunne belyse positive og negative effekter av legemiddelbruk

De fleste legemiddelmyndigheter i den vestlige verden gir nå farmakoepidemiologisk forskning økt prioritet, fordi de erkjenner et økende ansvar for å vurdere bruk av legemidler. Ved blant annet å belyse endringer $\mathrm{i}$ legemiddelbruk over tid og forske på langtidseffekter, vil grunnlaget for å øke kvaliteten på legemiddelbruken være lagt.

- Gi myndighetene et statistisk grunnlag for kvalitetssikring av legemiddelbruk og overordnet tilsyn, styring, planlegging

Opplysninger fra registeret skal ikke brukes til tilsyn med navngitte pasienter eller tilsyn med den enkelte leges forskrivning. Oppfølging av nasjonale eller regionale tendenser vil typisk falle innunder dette punktet. Myndighetene kan også benytte registeret til å utrede/evaluere regulatoriske tiltak knyttet til legemiddelområdet, inklusive legemiddeløkonomisk analyse. Registeret vil kunne bidra til et bedre beslutningsgrunnlag for helsemyndighetene.

\section{- Gi legemiddelrekvirenter et grunnlag for intern- kontroll og kvalitetsforbedring}

Registeret skal også bidra til kvalitetsutvikling av legemiddelforskrivning ved tilbakemelding til den enkelte lege på egen forskrivningsprofil. Dette skal skje ved at legen selv retter en henvendelse til pseudonymforvalteren om uttrekk fra registeret. 


\section{OPPLYSNINGER SOM SAMLES INN I RESEPT- REGISTERET}

Reseptregisteret skal kun være basert på opplysninger som fremkommer direkte eller indirekte av resepten og er de samme som normalt registreres ved ordinær behandling av resepter og rekvisisjoner i apotek. Et viktig prinsipp har vært at apotekene ikke skal bli pålagt nye rapporteringsoppgaver i forbindelse med opprettelsen av registeret, med unntak av fullt fødselsnummer. Krav om at pasientens fødselsnummer skal påføres resepten ble innført 1. oktober 2003 (Endring $i$ forskrift om rekvirering og utlevering av legemidler fra apotek 01.10.03).

I FarmaPro er det tilrettelagt for automatisk innsending av rapport til Reseptregisteret til fast tidspunkt hver måned, slik at apotekene kan oppfylle sin rapporteringsplikt (jf. Forskrift § 1-8 og kap. 2) uten vesentlig ekstra arbeid. Alle resepter og rekvisisjoner vil bli registrert, uavhengig av om det er legemiddel til pasient, dyr, forskrivers egen praksis, sykehjem/sykehus eller skip/forskning. Det faktum at alle apotek benytter FarmaPro til resepthåndtering, forenkler arbeidet med innsamling av data. Dette innebærer at registeret ideelt sett skal ha $100 \%$ dekning.

Følgende kategorier av opplysninger vil inngå i registeret:

- Personopplysninger om legemiddelbruker: pseudonym, kjønn, fødselsår, bostedskommune

- Personopplysninger om rekvirent: pseudonym, alder, kjønn, spesialitet

- Apotekkonsesjonsnummer

- Legemiddelopplysninger: varenummer, antall pakninger, forskrevet dosering (hvis angitt), refusjonspunkt (hvis angitt), evt. substitusjon med annet preparat enn forskrevet

- Prisopplysninger: utsalgspris, evt. egenandel og gebyrer

- Utleveringskategori

Krav om diagnosekode vil påføre rekvirent og apotek et betydelig merarbeid og er av den grunn ikke innført nå. Refusjonspunkt, som allerede er påført trygderesepter, skal imidlertid registreres. Refusjonspunktet vil for mange legemidler være å anse som en grov diagnosekode.

\section{SYSTEMLOSNING}

Karakteristisk for registeret er at det er store datamengder som skal håndteres. Estimerte tall viser at det på norske apotek ekspederes i størrelsesorden 26 mill. resepter årlig som omfatter rundt 35 mill. ordinasjoner. Dette representerer ca. $40 \mathrm{~GB}$ data per år. Registeret skal ha lang levetid og være tilgjengelig for mange ulike brukere (for eksempel forskere, helsepersonell, myndigheter).

Apotekene sender månedlig sine data til NAF-Data AS. Derfra går reseptene til tiltrodd pseudonymforvalter (TPF), som foretar pseudonymisering av pasientens fødselsnummer (11 siffer) og rekvirentens ID nummer (helsepersonellnummer), dvs. omdanner disse til løpenummer (pseudonymer). Det er viktig å merke seg at reseptopplysningene er kryptert og således ikke tilgjengelige for pseudonymforvalteren (jf. prinsipper for pseudonymisering). Statistisk sentralbyrå er utpekt til å være TPF for Reseptregisteret. Fra TPF sendes reseptene til Reseptregisteret for kvalitetskontroll og registrering. Krypterte nettverk ivaretar sikkerheten.

\section{PSEUdonymisering}

Etablering av en pseudonymiseringsløsning har vært en særlig utfordring, fordi Reseptregisteret er det første pseudonyme helseregister som etableres i Norge. Forbruket av legemidler til det enkelte individ må kunne følges over tid for at registeret skal kunne gi data som oppfyller formålet, og det skal gis mulighet for sammenstilling av opplysninger fra andre helseregistre med opplysninger fra Reseptregisteret. Det er nødvendig å ha en personentydig kode som skiller enkeltindividene fra hverandre. Fødselsnummer skal være et hjelpemiddel til å få etablert en slik entydig kode. Pasientens fødselsnummer og rekvirentens ID nummer er unike nøkler for pseudonymiseringen og må derfor registreres på apoteket før innsending til Reseptregisteret (Forskriftens § 1-8a). Unntatt fra kravet er resepter til dyr, der reseptinnehavers fødselsnummer ikke kreves.

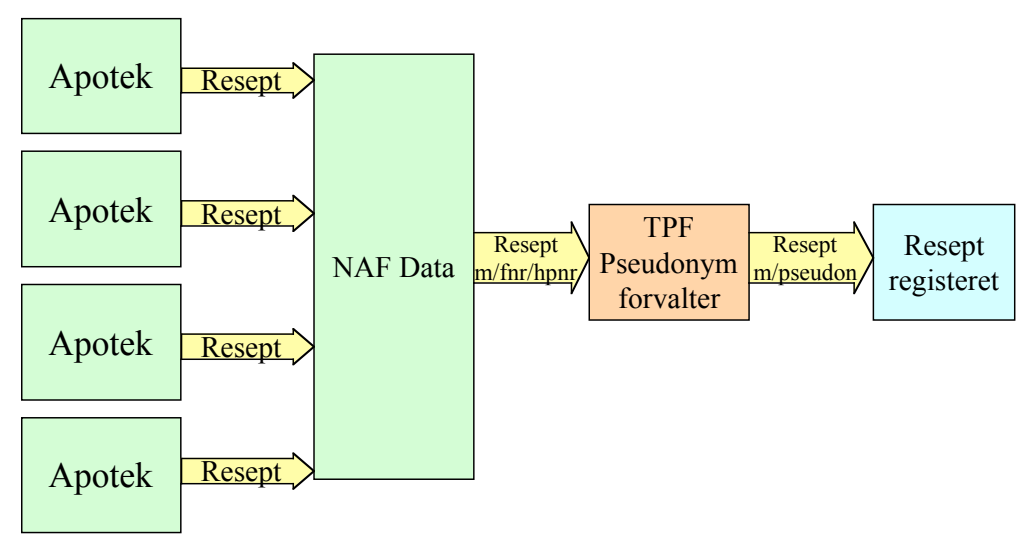

Figur 1. Dataflyt fra apotek til Reseptregisteret. 
Ved å opprette Reseptregisteret som et pseudonymt register ønsker myndighetene, i tillegg til å oppnå personentydighet, også å ivareta hensynet til konfidensialitet og informasjonssikkerhet.

Prinsippet for pseudonymisering er at ingen, heller ikke den som tildeler og forvalter pseudonymer, skal kunne ha samtidig tilgang til både pseudonym, helseopplysninger og personens identitet. Forutsetningen for at man skal kunne velge et pseudonymt register, er at tilbakemelding til kilden ikke er en nødvendighet, da pseudonymiseringsprosessen er irreversibel. Dette prinsippet er i forskriften uttrykt ved at det ikke er tillatt å gjenskape et fødselsnummer eller et helsepersonellnummer på grunnlag av et pseudonym. Av den grunn vil det være umulig å gi registrerte individer svar på hvilke data som er registrert om den enkelte.

\section{BRUK AV RESEPTREGISTERET}

Registeret vil ha forskjellige brukere med ulike behov for uttrekk av data. En åpenbar suksessfaktor for registeret vil være i hvilken grad informasjon kan gjøres tilgjengelig. For å møte kravene om tilgjengelighet og tilpassing, er det lagt opp til et webbasert grensesnitt, samt spesialuttrekk direkte fra databasen. Via webtilgang, skal ulike brukergrupper få tilgang til offentlig statistikk (for eksempel søk på ATC-kode), tilpassede rapporter (for eksempel kvartalsvise, halvårlige, årlige oversikter), rapporter om egen virksomhet (for eksempel periodisk oversikt over egen antibiotikaforskrivning) og standard spørringer på aggregert nivå (for eksempel antall ordinasjoner av et bestemt legemiddel fordelt på alder og kjønn). Eksempel på spesialuttrekk vil være sammenstilling av data fra andre sentrale helseregistre med data fra Reseptregisteret. Slike uttrekk vil kreve søknad til databehandlingsansvarlig for individuell vurdering. Figur 2 illustrerer hvordan ulike brukergrupper er tenkt å få tilgang til informasjon fra databasen.

\section{INFORMASJON TIL PUBLIKUM}

For at apotekene skal kunne oppfylle sin informasjonsplikt (jf. Forskriftens $\S 2-1$ ), har Folkehelseinstituttet i samarbeid med apotekkjedene og helsedepartementet utarbeidet informasjonsmateriell bestående av plakater og publikumsbrosjyrer. Plakaten skal være godt synlig på alle apotek i området for reseptinnlevering. Brosjyrene gir detaljert informasjon om Reseptregisteret til pasienter som etterspør dette. Apotek med fjernkunder må vedlegge brosjyren ved første reseptforsendelse den første måneden, med mindre apoteket vet at kunden har denne informasjonen fra før. Reseptregisteret skal vare komplett, og det er derfor ikke anledning til å reservere seg mot å bli registrert.

Ikke bare forskere og myndigheter, men også allmennheten skal kunne få tilgang til data fra registeret. Dette er nevnt i publikumsbrosjyren. Ettersom statistikk med lite data kan være vanskelig å tolke, vil det først legges til rette for publikumstilgang når tilstrekkelig data er foreligger. Det skal ligge informasjon om dette på Folkehelseinstituttets nettside.

Reseptregisteret vil være et viktig verktøy for å oppnå en detaljert legemiddelstatistikk i Norge. Dette vil på sikt gi et bedre grunnlag for mer rasjonell legemiddelbruk i befolkningen.

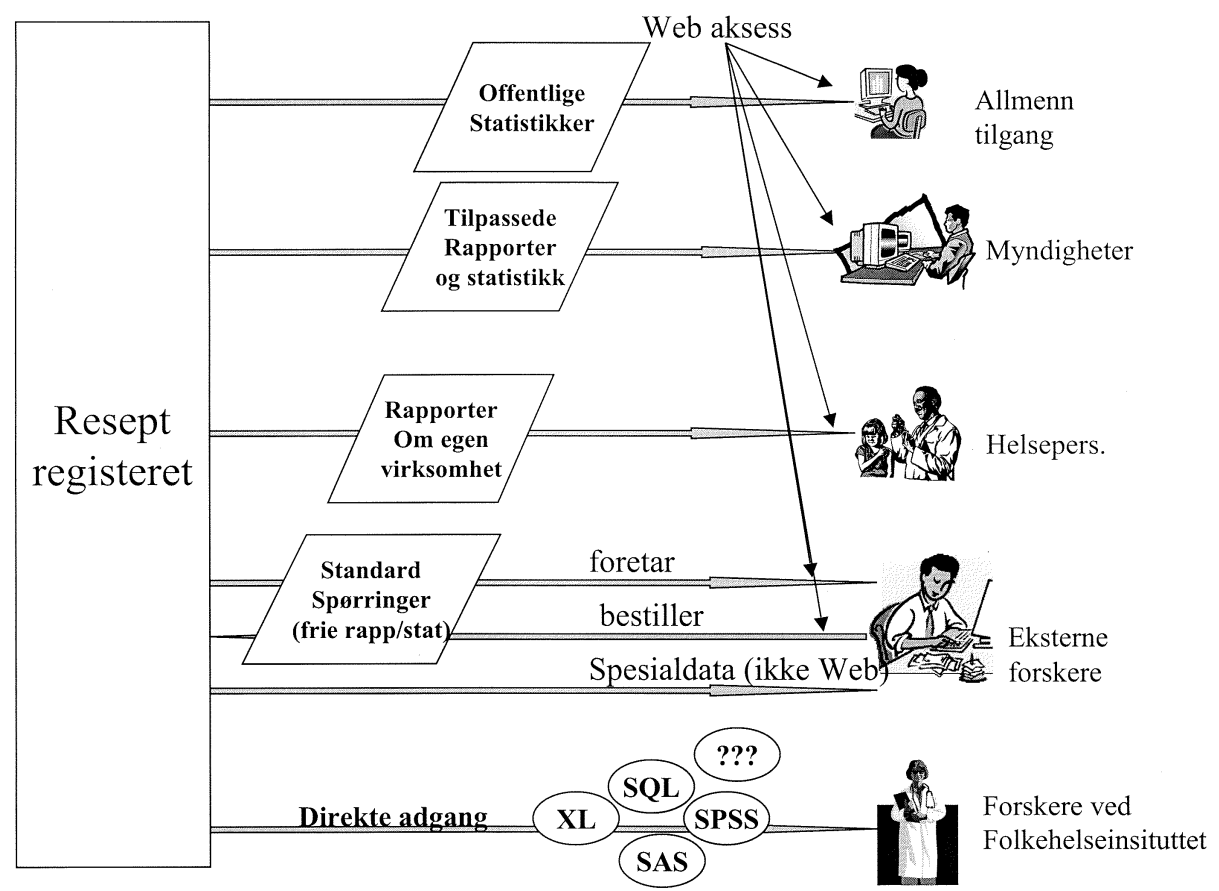

Figur 2. Tilgang til informasjon fra Reseptregisteret. 